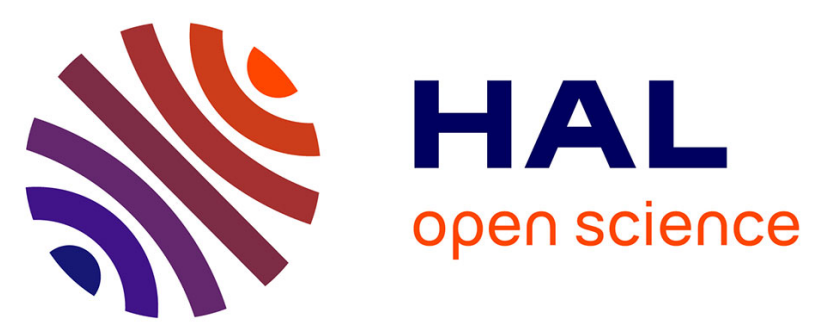

\title{
Antibacterial activity of terpenoids isolated from Cnidoscolus quercifolius Pohl (Euphorbiaceae), a Brazilian medicinal plant from Caatinga biome
}

Raimundo Gonçalves de Oliveira-Júnior, Christiane Adrielly Alvez Ferraz, Michelle Cruz Pontes, Noelly Bastos Cavalcante, Edigênia Cavalcante da Cruz Araújoa, Ana Paula de Oliveira, Laurent Picot, Larissa Araújo Rolim, Jackson Roberto Guedes da Silva Almeida

\section{- To cite this version:}

Raimundo Gonçalves de Oliveira-Júnior, Christiane Adrielly Alvez Ferraz, Michelle Cruz Pontes, Noelly Bastos Cavalcante, Edigênia Cavalcante da Cruz Araújoa, et al.. Antibacterial activity of terpenoids isolated from Cnidoscolus quercifolius Pohl (Euphorbiaceae), a Brazilian medicinal plant from Caatinga biome. European Journal of Integrative Medicine, 2018, 24, pp.30-34. 10.1016/j.eujim.2018.10.011 . hal-01900949

HAL Id: hal-01900949

https: / hal-univ-rochelle.archives-ouvertes.fr/hal-01900949

Submitted on 22 Oct 2018

HAL is a multi-disciplinary open access archive for the deposit and dissemination of scientific research documents, whether they are published or not. The documents may come from teaching and research institutions in France or abroad, or from public or private research centers.
L'archive ouverte pluridisciplinaire HAL, est destinée au dépôt et à la diffusion de documents scientifiques de niveau recherche, publiés ou non, émanant des établissements d'enseignement et de recherche français ou étrangers, des laboratoires publics ou privés. 


\section{Antibacterial activity of terpenoids isolated from Cnidoscolus quercifolius Pohl (Euphorbiaceae), a Brazilian medicinal plant from Caatinga biome}

Raimundo Gonçalves de Oliveira-Júnior ${ }^{\mathrm{a}}$, Christiane Adrielly Alves Ferraz ${ }^{\mathrm{a}}$, Michelle Cruz Pontes ${ }^{\mathrm{a}}$, Noelly Bastos Cavalcante ${ }^{\mathrm{a}}$, Edigênia Cavalcante da Cruz Araújo ${ }^{\mathrm{a}}$, Ana Paula de Oliveira ${ }^{\mathrm{a}}$, Laurent $\operatorname{Picot}^{\mathrm{b}}$, Larissa Araújo Rolim ${ }^{\mathrm{a}}$, Jackson Roberto Guedes da Silva Almeida ${ }^{\mathrm{a},{ }^{*}}$

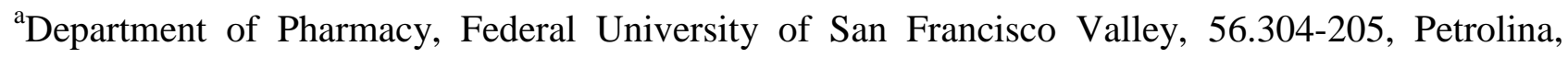
Pernambuco, Brazil.

${ }^{\mathrm{b}}$ Faculty of Science and Technology, UMRi CNRS 7266 LIENSs, University of La Rochelle, La Rochelle, France.

*Correspondence: Jackson R.G.S. Almeida, Universidade Federal do Vale do São Francisco, 56.304-205, Petrolina, PE, Brazil. E-mail: jackson.guedes@univasf.edu.br; Phone/Fax: +55-8721016862 


\begin{abstract}
Introduction: Cnidoscolus quercifolius Pohl (Euphorbiaceae) is a Brazilian medicinal plant, popularly known as "favela", "faveleira" and "urtiga-branca". In folk medicine, its leaves and stem barks are used to treat urinary tract infections. In this study, we report the isolation and characterization of a mixture of two lupane-type triterpenes and one bis-nor-diterpene from the hexane extract of the stem barks.

Methods: An aliquot of hexane extract was fractioned by means silica gel chromatography column, yielding a mixture of two compounds ( $\mathbf{1}$ and $\mathbf{2}$ ). Compound $\mathbf{3}$ was obtained from the chloroform subfraction through preparative thin layer chromatography (TLC). The compounds were identified by comparison of their spectroscopic data to those reported in the literature. The antibacterial activity of these compounds was evaluated by the microdilution method, through determination of minimum inhibitory concentration (MIC) and minimum bactericidal concentration (MBC), using gram-positive (E. faecalis and $S$. aureus) and gram-negative (E. coli, K. pneumoniae and $S$. marcescens) strains.
\end{abstract}

Results: The chemical constituents were identified as a mixture of lupeol-3 $\beta$ - $O$-cinnamate (1) and lupeol-3ß-O-dihydrocinnamate (2) and, phyllacanthone (3). Compounds $\mathbf{1 / 2}$ and $\mathbf{3}$ showed a bacteriostatic effect ten and twenty times higher (MIC $=0.5$ and $0.25 \mathrm{mg} \cdot \mathrm{ml}^{-1}$, respectively) than the hexane extract, respectively $\left(\mathrm{MIC}=5.0 \mathrm{mg} \cdot \mathrm{ml}^{-1}\right)$. The molecules also showed a relevant bactericidal effect, mainly compound $\mathbf{3}\left(\mathrm{MBC}=0.25 \mathrm{mg} \cdot \mathrm{ml}^{-1}\right)$.

Conclusion: These results suggest that $C$. quercifolius may be considered a promising source of new antibacterial agents. In addition, this investigation supports the medicinal use of this plant for the treatment of urinary tract infections.

Keywords: Cnidoscolus; medicinal plant; triterpene; diterpene; antibacterial activity. 


\section{Introduction}

The use of antibiotics is widely described in many clinical situations, including in the control of infections during invasive surgeries, in cancer chemotherapy and in the treatment of immune-compromised patients [1]. In recent years, antibiotic resistance has become a serious health problem, leading to the emergence of microorganisms resistant to conventional chemotherapy [2]. In this sense, infectious diseases caused by antibiotic resistant microorganisms have been frequently reported $[3,4]$. For this reason, the search for new antimicrobial molecules from natural products remains an effective alternative [5-7].

Euphorbiaceae is a pantropical family containing approximately 300 genera and 7000 species, including trees, shrubs and herbs, of which 70 genera and 1000 species occur in Brazil [8]. The neotropical genus Cnidoscolus Pohl is represented by 70 species [9,10]. In Brazil, there are 42 Cnidoscolus species distributed in different geographical areas, such as Cerrado, Atlantic Forest, Amazon and Caatinga biome [11,12].

Cnidoscolus quercifolius Pohl (syn.: Cnidoscolus phyllacanthus (Mull. Arg.) Pax \& L. Hoffm.) is a Brazilian medicinal plant from Caatinga biome, popularly known as "favela", "faveleira" and "urtiga-branca". In folk medicine, its leaves and stem barks are used to treat injury, urinary tract infections and inflammatory processes [13]. Previous pharmacological investigations evaluated the antinociceptive [14], anti-inflammatory [15], antioxidant [16,17], antiproliferative $[18,19]$ and antibacterial $[17,20]$ effects of crude extracts from C. quercifolius.

From a phytochemical point of view, lupane-type triterpenes and bis-nor-diterpenes have been reported in C. quercifolius [21]. New tricyclic benzocyclohepten diterpenes, called favelins, were isolated from stem barks extracts [22]. New cyclopropane and cyclobutene tetracyclic derivatives, such as favelanone and neofavelanone, respectively, were also described in previous phytochemical studies [23,24]. Apparently, these diterpenes occur exclusively in C. quercifolius. 
Although $C$. quercifolius extracts have been investigated for their antibacterial potential, there are no reports on the antibacterial activity of compounds isolated from this species.

Considering the popular use of this plant for the treatment of infections, the present study describes the antibacterial activity of terpenoids isolated from the stem barks of $C$. quercifolius against pathogenic strains.

\section{Materials and methods}

\subsection{Plant material}

Stem barks of $C$. quercifolius were collected in the city of Petrolina (coordinates $09^{\circ} 24^{\prime}$ 40.97" S and 40 32' 49.19" W), state of Pernambuco, Brazil, in February 2015. A voucher specimen ( ${ }^{\circ}$ 19202) has been deposited at the Herbário do Vale do São Francisco (HVASF), of the Universidade Federal do Vale do São Francisco (UNIVASF).

\subsection{Extraction and isolation}

The dried and pulverized stem barks (534 g) were extracted with hexane (2.0 L, four times), followed by methanol (2.0 L, four times), yielding 8.7 and $18.5 \mathrm{~g}$ of hexane and methanol extracts (Hex-Cq and $\mathrm{MeOH}-\mathrm{Cq}$, respectively) after removal of the solvents under vacuum. An aliquot of Hex-Cq (7.0 g) was fractionated by chromatography column, using silica gel 60 (Sigma-Aldrich ${ }^{\circledR}$, 230-240 mesh) as stationary phase. Hexane, chloroform $\left(\mathrm{CHCl}_{3}\right)$, ethyl acetate (AcOEt) and methanol $(\mathrm{MeOH})$ were used as eluents, in increasing order of polarity. In total, 42 fractions (125 $\mathrm{ml}$ each) were collected and reunited in 13 different groups (groups A-M), after TLC analysis. Group D (eluted with hexane/ $\mathrm{CHCl}_{3}$ 2.5:7.5, v/v) showed the formation of white crystals $(635 \mathrm{mg}$ ) soluble in chloroform, which was subsequently identified as a mixture of two compounds (1 and 2). 
Group F (eluted with $\left.\mathrm{CHCl}_{3}\right)$ was fractionated by preparative TLC, using hexane/AcOEt $(9: 1, v / v)$ as eluent, leading to the isolation of compound $\mathbf{3}$ (13.7 $\mathrm{mg}$, yellow crystals soluble in chloroform).

\subsection{Spectroscopic analysis}

NMR spectra $\left({ }^{1} \mathrm{H},{ }^{13} \mathrm{C}\right.$, DEPT-135, COSY, HSQC and HMBC) were recorded on a Bruker Ascend ${ }^{\circledR}$ (400 MHz for ${ }^{1} \mathrm{H}$ and $100 \mathrm{MHz}$ for ${ }^{13} \mathrm{C}$ ) spectrometer, at $25{ }^{\circ} \mathrm{C}$ and with $\mathrm{CDCl}_{3}$ as solvent (internal standard $0.05 \%$ TMS, Tedia ${ }^{\circledR}$, Brazil). Chemical shifts are given in ppm values $(\delta)$ and coupling constants $(J)$ in Hz. In addition, retention factor $\left(\mathrm{R}_{\mathrm{f}}\right)$ was calculated for each compound, through TLC analysis, using the same eluent (hexane/AcOEt, 9.5:0.5, v/v). TLC plates were visualized in UV chamber (254 and $365 \mathrm{~nm}$ ) and, subsequently, revealed with $1 \%$ sulfuric vanillin solution.

\subsection{Antibacterial activity}

\subsubsection{Bacteria strains assay}

Reference bacterial strains were obtained from National Institute of Quality Control in Health (INCQS/FIOCRUZ, Brazil). The pathogenic microorganisms used were Enterococcus faecalis $\left(\mathrm{ATCC}^{\circledR}\right.$ 19433), Escherichia coli $\left(\mathrm{ATCC}^{\circledR}\right.$ 25922), Klebsiella pneumoniae (ATCC $^{\circledR}$ 13883), Serratia marcescens (ATCC $\left.{ }^{\circledR} 13880\right)$ and Staphylococcus aureus $\left(\mathrm{ATCC}^{\circledR} 25923\right)$.

\subsubsection{Determination of minimum inhibitory concentration (MIC)}

Antibacterial activity was evaluated by the microdilution method, as recommended by National Committee for Clinical Laboratory Standards [25]. Stock solutions of extracts (Hex-Cq and $\left.\mathrm{MeOH}-\mathrm{Cq}, 20 \mathrm{mg} \cdot \mathrm{ml}^{-1}\right)$ and isolated compounds (1/2 and 3, $2 \mathrm{mg} \cdot \mathrm{ml}^{-1}$ ) were prepared in $2 \%$ 
$\operatorname{DMSO}(v / v)$. Subsequently, $100 \mu \mathrm{l}$ of this solution was added to microplates containing $100 \mu \mathrm{l}$ of Müller-Hinton broth, in order to obtain final concentrations of $10-0.16 \mathrm{mg} \cdot \mathrm{ml}^{-1}$ (for extracts) and 1 - $0.008 \mathrm{mg} \cdot \mathrm{ml}^{-1}$ (for isolated compounds). Gentamicin was used as positive control (final concentrations of $1.6-0.012 \mathrm{mg} \cdot \mathrm{ml}^{-1}$ ). Wells were reserved for sterility control of the broth (negative control). Finally, an inoculum containing $5 \times 10^{5} \mathrm{CFU}_{\mathrm{ml}}{ }^{-1}$ (0.5 in McFarland scale) was added to each well and microplates were maintained under aerobic conditions $\left(37^{\circ} \mathrm{C}\right.$, during $18-24$ hours). After incubation, $10 \mu \mathrm{l}$ of 2\% 2,3,5-triphenyl-tetrazolium (CTT) solution $(v / v)$ were added to each well to detect the color change of the CTT (colorless) to red, reflecting the bacterial metabolism active. MIC was defined as the lowest concentration of extracts or compounds that visibly inhibited the bacterial growth in three independent experiments.

\subsubsection{Determination of minimum bactericidal concentration (MBC)}

To determine MBC, an aliquot (10 $\mu \mathrm{l})$ was withdrawn from each well containing extracts or isolated compounds and transferred to Petri dishes containing agar Müller-Hinton. Plates were incubated for $24 \mathrm{~h}$ in the same conditions previously described. The absence of bacterial colony for a given concentration indicates that it was able to kill $99.9 \%$ or more of bacterial inoculum used. MBC was defined as the lowest concentration of extracts or compounds that visibly inhibited the bacterial colony production in three independent experiments.

\section{Results}

\subsection{Structural characterization of isolated compounds}

TLC analysis revealed a good degree of purity for the isolated compounds. Compound $\mathbf{3}$ showed fluorescence at $365 \mathrm{~nm}$, suggesting the presence of an aromatic ring in its structure. In 
addition, TLC analysis using sulfuric vanillin revealed the presence of purple spots, indicating that these compounds were terpenes (Fig. 1).

After careful NMR (1D and 2D) analysis, as well as comparison with spectral data reported

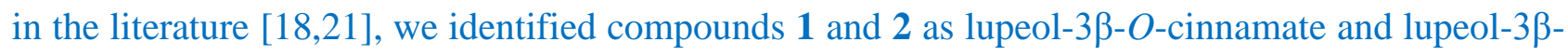
$O$-dihydrocinnamate, respectively. The presence of a lupeol unit in both molecules was recognized by chemical shifts and multiplicity of all ${ }^{1} \mathrm{H}$ and ${ }^{13} \mathrm{C}$ NMR signals. ${ }^{1} \mathrm{H}$ NMR spectra showed two broad singlet signals for two ethylenic protons (H-29, $\delta 4.70$ and 4.58), and two singlet signal attributed to methyl groups (H-30, $\delta 1.69$ for compound $\mathbf{1}$, and $\delta 1.68$ for compound 2), compatible for lupeol units. ${ }^{13} \mathrm{C}$ NMR spectra displayed signals at $\delta 172.8$ and 166.9 , indicating the presence of an ester function for both compounds. Two signals for carbinolic protons $(\mathrm{H}-3)$ at $\delta 4.63(\mathrm{dd}, J=$ 10.4 and $5.2 \mathrm{~Hz})$ and $4.48(\mathrm{dd}, J=10.4$ and $5.6 \mathrm{~Hz})$ suggested that the site of esterification was at C-3 (A ring of the basic skeleton of lupeol). ${ }^{1} \mathrm{H}$ NMR spectra also indicated a cinnamyl group for compound 1 through the signals at $\delta$ 7.28-7.53 (m, H-2'/6', H-3'/5' and H-4'), 7.67 (d, $J=16 \mathrm{~Hz}$, H-7') and 6.45 (d, $\left.J=16 \mathrm{~Hz}, \mathrm{H}-8^{\prime}\right)$. A 7',8'-dihydrocinnamyl group corresponding to the major component 2 was indicated by the signals $\delta 2.96$ (t, H-7') and 2.63 (t, H-8') [21]. The intensities (revealed integration) of the signals at $\delta 7.67\left(\mathrm{H}-7^{\prime}\right.$ ' for compound $\left.\mathbf{1}\right)$ and $2.96\left(\mathrm{H}-7^{\prime}\right.$ ' for compound 2) were used to estimate the relative proportions of them in the mixture: $25 \%$ of $\mathbf{1}$ (approximately $159 \mathrm{mg}$ ) and $75 \%$ of $\mathbf{2}$ (approximately $476 \mathrm{mg}$ ).

${ }^{1} \mathrm{H}$ NMR spectra for compound 3 displayed two singlets at $\delta 7.62(\mathrm{H}-1)$ and $6.59(\mathrm{H}-4)$, attributed to two protons para-related, and another singlet signal at 6.29 (H-11), attributed to a vinyl hydrogen. ${ }^{13} \mathrm{C}$ NMR spectra showed a signal at $\delta 201.5$, attributed to a ketone group, suggesting the presence of an acetophenone unit. ${ }^{1} \mathrm{H}$ NMR spectra also revealed signals for two methyl groups attached to a quarternary $\mathrm{sp}^{3}$ carbon $[\delta 0.75(\mathrm{~s}, \mathrm{H}-16)$ and 1.12 (s, H-17)], and one methyl group attached to a sp ${ }^{2}$ carbon $[\delta 2.18(\mathrm{~s}, \mathrm{H}-18)]$. The identification of a methoxy group [ $\left.\delta 3.87(\mathrm{~s}, \mathrm{H}-19)\right]$ led to the molecular formula $\mathrm{C}_{18} \mathrm{H}_{21} \mathrm{O}$ for the basic skeleton, compatible for a bis-nor-diterpene. Homonuclear and heteronuclear shift correlations $\left({ }^{1} \mathrm{H}-{ }^{1} \mathrm{H}\right.$ COSY and ${ }^{13} \mathrm{C}-{ }^{1} \mathrm{H} \mathrm{HMBC}$, respectively) 
confirmed the substitution pattern of the aromatic ring and all ${ }^{1} \mathrm{H}$ and ${ }^{13} \mathrm{C}$ assignments. These data allowed the unambiguous structural characterization of compound $\mathbf{3}$ as the bis-nor-diterpene phyllacanthone [21]. All the spectra data obtained for each compound are shown in the supplementary material.

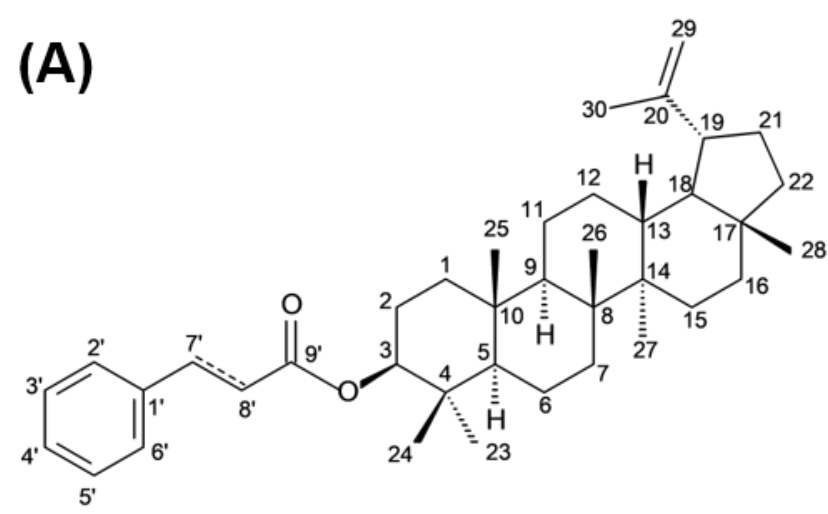

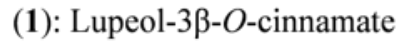

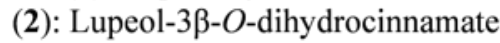

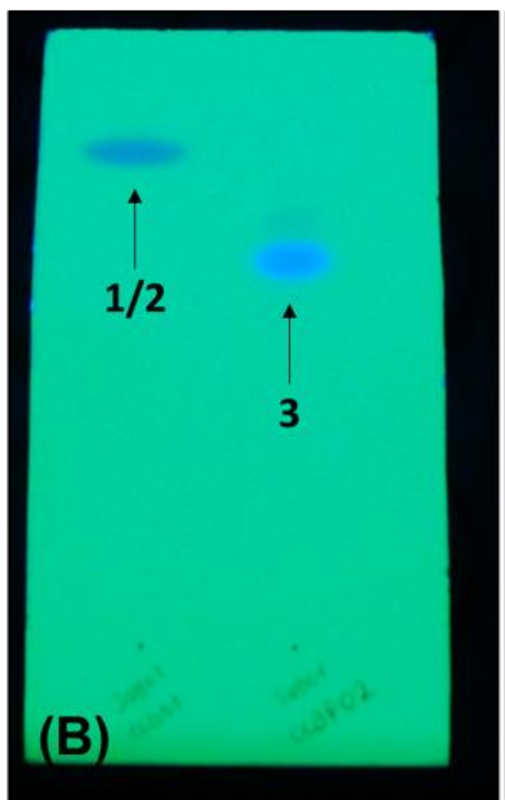

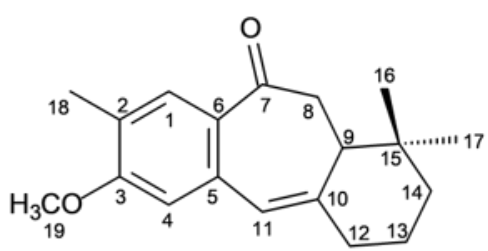

(3): Phyllacanthone
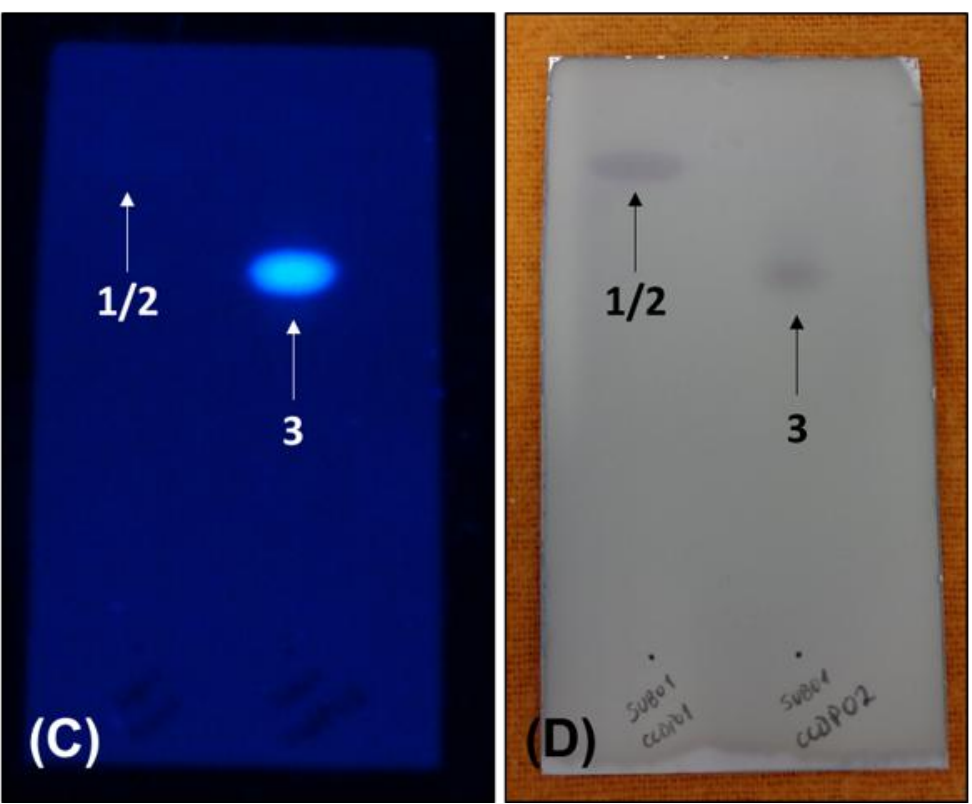

Fig. 1. Chemical structures (A) and analytical TLC plates (eluent: hexane-ethyl acetate, 95:5) of compounds $\mathbf{1 / 2}$ and $\mathbf{3}$, visualized in an UV radiation chamber at 254 (B) and $365(\mathrm{C}) \mathrm{nm}$, and after staining with $1 \%$ sulfuric vanillin (D).

\subsection{Antibacterial activity}


The MIC values determined for the samples are presented in Table $1 . \mathrm{Cq}-\mathrm{Hex}$ and $\mathrm{Cq}-$ $\mathrm{MeOH}$ displayed weak antibacterial activity. However, compounds 1/2 and 3 showed MIC values ten and twenty times lower $\left(0.5\right.$ and $0.25 \mathrm{mg} \cdot \mathrm{ml}^{-1}$, respectively) than those verified for both extracts (5.0 mg. $\mathrm{ml}^{-1}$ ) against all bacteria strains. Furthermore, the isolated compounds demonstrated MBC values between 0.25 and $0.5 \mathrm{mg} \cdot \mathrm{ml}^{-1}$, suggesting that these molecules also exert a bactericidal effect (Table 2). In this case, compound $\mathbf{3}$ was more effective than gentamicin against $E$. faecalis and $E$. coli.

Table 1. Minimum inhibitory concentration (MIC, mg.ml ${ }^{-1}$ ) of extracts (Hex-Cq and $\left.\mathrm{MeOH}-\mathrm{Cq}\right)$ and isolated compounds (1/2 and $\mathbf{3})$ from $C$. quercifolius.

\begin{tabular}{lccccc}
\hline Microorganism & \multicolumn{3}{c}{ MIC $\left(\mathbf{m g} \cdot \mathbf{m l}^{-\mathbf{1}}\right)$} \\
& Cq-Hex & Cq-MeOH & $\mathbf{1 / 2}$ & $\mathbf{3}$ & Gentamicin \\
\cline { 2 - 6 } E. faecalis & 5.0 & 5.0 & 0.5 & 0.25 & 0.40 \\
E. coli & 5.0 & 5.0 & 0.5 & 0.25 & $*$ \\
K. pneumoniae & 5.0 & 5.0 & 0.5 & 0.25 & 0.05 \\
S. marcescens & 5.0 & 5.0 & 0.5 & 0.25 & $*$ \\
S. aureus & 5.0 & 5.0 & 0.5 & 0.25 & 0.025
\end{tabular}

* Absence of bacterial growth in all tested concentrations $(n=3)$. 
Table 2. Minimum bactericidal concentration (MBC, mg.ml ${ }^{-1}$ ) of extracts (Hex-Cq and MeOH-Cq) and isolated compounds (1/2 and $\mathbf{3})$ from $C$. quercifolius.

\begin{tabular}{lccccc}
\hline Microorganism & \multicolumn{5}{c}{ MBC $\left(\mathbf{m g} \cdot \mathbf{m l}^{\mathbf{- 1}}\right)$} \\
\cline { 2 - 6 } & Cq-Hex & Cq-MeOH & $\mathbf{1 / 2}$ & $\mathbf{3}$ & Gentamicin \\
\hline E. faecalis & $>10$ & $>10$ & 0.5 & 0.25 & 0.40 \\
E. coli & $>10$ & $>10$ & 0.5 & 0.25 & 0.40 \\
K. pneumoniae & $>10$ & $>10$ & 0.5 & 0.25 & 0.05 \\
S. marcescens & $>10$ & $>10$ & 0.5 & 0.25 & 0.025 \\
S. aureus & $>10$ & $>10$ & 0.5 & 0.25 & 0.025 \\
\hline$>10$ indicates & & & &
\end{tabular}

$>10$ indicates bacterial growth in all tested concentrations $(n=3)$.

\section{Discussion}

Compounds 1 and $\mathbf{2}$ have previously been described in C. quercifolius [18,21]. In fact, these compounds are frequently obtained as a mixture, due to its structural similarity. This mixture has also been reported in $C$. vitifolius [26]. Other lupane-type triterpenes were reported in $C$. quercifolius, such as lupeol [21] and lupeol-3 $\beta-O$-nanoate [18]. Compound $\mathbf{3}$ is a bis-nor-diterpene commonly found in C. quercifolius [18,21,27]. Also known as faveline-methyl-ether, phyllacanthone (3) was one of the first isolated substances from this plant. To date, there are no reports of other species that present this chemical constituent in its composition, being considered of exclusive occurrence in C. quercifolius. A recent study demonstrated the cytotoxic potential of phyllacanthone (3) against human pro-myelocytic leukemia (HL-60), human lung carcinoma (NCIH292) and human breast adenocarcinoma (MCF-7) cells [18]. However, these compounds have not been sufficiently investigated for their biological activities.

In this paper, we evaluated the antibacterial activity of extracts ( $\mathrm{Hex}-\mathrm{Cq}$ and $\mathrm{MeOH}-\mathrm{Cq})$ and isolated compounds (1/2 and $\mathbf{3}$ ) against pathogenic bacteria strains. In general, compounds $\mathbf{1 / 2}$ and $\mathbf{3}$ were effective against all the microorganisms used. Interestingly, compound $\mathbf{3}$ was more effective 
than the standard drug (gentamicin) against E. faecalis and E. coli strains. Although it is present in the human gastrointestinal microbiota, E. faecalis is considered an opportunistic pathogen associated with hospital-acquired wound, bloodstream, and urinary tract infections [28]. Similarly, E. coli is also among the most frequent pathogens found in urinary tract infections. These microorganisms are able to persist in the host for long periods through formation of biofilm that prevents phagocytosis by immune system cells [29]. In addition, both microorganisms have developed multidrug resistance mechanisms in recent years, making it difficult to control associated infections [30,31]. In this context, the search for bioactive molecules that can treat E. faecalis and E. coli infections remains a current challenge.

Terpenoids are admittedly used in the treatment of bacterial infections. Due to their lipophilic character, terpenoids can easily interact with the bacterial wall, interfering with the biosynthesis of its components. Furthermore, these compounds penetrate the bacterial cell and may also interfere with protein synthesis and DNA replication and repair mechanisms. In recent years, terpenoids have shown ability to enhance the effect of conventional antibacterial drugs. This has been an extremely useful strategy in controlling antibiotic resistance. These molecules have modulated the effect of antibacterial agents either by promoting direct cytotoxicity or by increasing their residence time in the cell, ensuring greater pharmacological activity at lower concentrations [32]. In this sense, compounds isolated from C. quercifolius may play an important role not only in the control of bacterial infections, especially those caused by E. faecalis and E. coli, but also in the control of multidrug resistance mechanisms. In vivo studies should be performed to determine the toxicity of these molecules, as well as their pharmacokinetic properties, associated or not with other antibacterial agents.

Peixoto-Sobrinho et al. [20] have reported the antibacterial activity of four Cnidoscolus species (C. infestus Pax and K. Hoffman, C. pubescens Pohl, C. urens (L.) Arthur and C. quercifolius) using the agar diffusion method. In this study, C. quercifolius extracts were the most bioactive, showing a relevant bacteriostatic effect against $S$. aureus. However, this was a 
preliminary study conducted with crude extracts. In the present paper, we report the isolation of antibacterial compounds from $C$. quercifolius extracts for the first time. We believe that these compounds are responsible, at least in part, for the antibacterial potential observed for the extracts. These findings suggest that this plant may be considered a promising source of new antibacterial agents and further studies should be performed in order to characterize their mode of action.

\section{Conclusions}

In this phytochemical investigation, we report the isolation and characterization of three

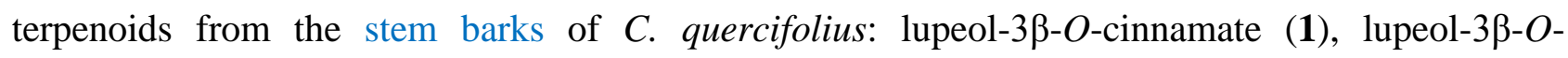
dihydrocinnamate and phyllacanthone (3). The isolated substances showed significant antibacterial activity, mainly compound $\mathbf{3}$. These results indicate that $C$. quercifolius has antibacterial potential, supporting its use in folk medicine in the treatment of urinary tract infections.

\section{Acknowledgment}

The authors thank FACEPE (Fundação de Amparo à Ciência e Tecnologia do Estado de Pernambuco) and CNPq (Conselho Nacional de Desenvolvimento Científico e Tecnológico) for the financial support.

\section{Conflict of interests}

All authors declare that there is no conflict of interest for the publication of this manuscript. 


\section{References}

[1] D. Hughes, A. Karlén, Discovery and preclinical development of new antibiotics. Ups. J. Med. Sci. 119 (2014) 162-169.

[2] J. Srivastava, H. Chandra, A.R. Nautiyal, S.J.S. Kalra, Antimicrobial resistance (AMR) and plant-derived antimicrobials (PDAms) as an alternative drug line to control infections. 3 Biotech. 4 (2014) 451-460.

[3] C.L. Ventola, The Antibiotic Resistance Crisis, Part 1: Causes and Threats. P. T. 40 (2015) 277283.

[4] J.M. Blair, M.A. Webber, A.J. Baylay, D.O. Ogbolu, L.J. Piddock, Molecular mechanisms of antibiotic resistance. Nat. Rev. Microbiol. 13 (2015) 42-51.

[5] H. Chandra, P. Bishnoi, A. Yadav, B. Patni, A.P. Mishra, A.R. Nautiyal, Antimicrobial Resistance and the Alternative Resources with Special Emphasis on Plant-Based Antimicrobials-A Review. Plants. 10 (2017) 1-11.

[6] D.G. Brown, T. Lister, T.L. May-Dracka, New natural products as new leads for antibacterial drug discovery. Bioorg. Med. Chem. Lett. 24 (2014) 413-418.

[7] M.G. Moloney, Natural Products as a Source for Novel Antibiotics. Trends. Pharmacol. Sci. 37 (2016) 689-701.

[8] V.C. Souza, H. Lorenzi, Botânica Sistemática: guia ilustrado para identificação das famílias de Angiospermas da flora brasileira. Instituto Plantarum, São Paulo, 2005.

[9] G.L. Webster, Systematics of the Euphorbiaceae. Ann. Missouri. Bot. Gard. 81 (1994) 1-144.

[10] M.M. Gordillo, J.J. Rámirez, R.C. Durán, E.J. Arriaga, R. García, A. Cervantes, R.M. Hernández, Los géneros de la familia Euphorbiaceae en México. Anal. Inst. Biol. 73 (2002) 155-281.

[11] A.L. Melo, M.F. Sales, O gênero Cnidoscolus Pohl (Crotonoideae-Euphorbiaceae) no estado de Pernambuco, Brasil. Acta. Bot. Bras. 22 (2008) 806-827.

[12] K.J. Wurdack, C.C. Davis, Malpighiales phylogenetics: Gaining ground on one of the most recalcitrant clades in the angiosperm tree of life. Am. J. Bot. 96 (2009) 1551-1570.

[13] U.P. Albuquerque, P.M. Medeiros, A.L.S. Almeida, J.M. Monteiro, E.M.F. Lins-Neto, J.M. Gomes, J.P. Santos, Medicinal plants of the Caatinga (semi-arid) vegetation of NE Brazil: a quantitative approach. J. Ethnopharmacol. 114 (2007) 325-354.

[14] L.M.C. Gomes, S.R.G. Lima-Saraiva, T.M.D. Andrade, J.C. Silva, T.C. Diniz, V.N.S. Barreto, R.L. Mendes, L.J. Quintans-Júnior, J.S.S. Quintans, J.T. Lima, J.R.G.S. Almeida, Antinociceptive activity of the ethanolic extract from barks and leaves of Cnidoscolus quercifolius (Euphorbiaceae) in mice. J. Young. Pharm. 6 (2014) 64-69. 
[15] L.M.A. Gomes, T.M.D. Andrade, J.C. Silva, J.T. Lima, L.J. Quintans-Júnior, J.R.G.S. Almeida, Phytochemical screening and anti- inflammatory activity of Cnidoscolus quercifolius (Euphorbiaceae) in mice. Pharmacogn. Res. 6 (2014) 345-349.

[16] T.J. Peixoto-Sobrinho, V.T.N.A. Castro, A.M. Saraiva, D.M. Almeida, E.A. Tavares, E.L.C. Amorim, Phenolic content and antioxidant capacity of four Cnidoscolus species (Euphorbiaceae) used as ethnopharmacologicals in Caatinga, Brazil. Afr. J. Pharm. Pharmacol. 5 (2011) 2310-2316.

[17] P.F.M. Paredes, F.R. Vasconcelos, R.T.T. Paim, M.M.M. Marques, S.M. Morais, S.M. Lira, I.D. Braquehais, I.G.P. Vieira, F.N.P. Mendes, M.I.F. Guedes, Screening of Bioactivities and Toxicity of Cnidoscolus quercifolius Pohl. Evid. Based. Complement. Alternat. Med. 2016 (2016) 1-9.

[18] A.C. Paula, K.M. Melo, A.M. Silva, D.A. Ferreira, F.J.Q. Monte, G.M.P. Santiago, T.L.G. Lemos, R. Braz-Filho, G.C.G. Militão, P.B.N. Silva, T.G. Silva, Constituintes Químicos e Atividade Citotóxica de Cnidoscolus phyllacanthus. Rev. Virtual. Quim. 8 (2016) 231-241.

[19] T.J. Peixoto-Sobrinho, E.A. Tavares, V.T.N.A. Castro, J. Veras-Filho, G.C.G. Militão, T.G. Silva, E.L.C. Amorim, Antiproliferative activity of species of the genus Cnidoscolus against HT-29, Hep-2 and NCI-H292 cells. Mol. Clin. Pharmacol. 3 (2012) 55-61.

[20] T.J. Peixoto-Sobrinho, V.T.N.A. Castro, A.M. Saraiva, D.M. Almeida, E.A. Tavares, M.N.C. Pisciottano, E.L.C. Amorim, Phytochemical screening and antibacterial activity of four Cnidoscolus species (Euphorbiaceae) against standard strains and clinical isolates. J. Med. Plan. Res. 6 (2012) 3742-3748.

[21] T.L.G. Lemos, E.R. Silveira, M.F. Oliveira, R. Braz-Filho, Terpenoids from Cnidoscolus phyllacanthus Pax et Hoff. J. Braz. Chem. Soc. 2 (1991) 105-110.

[22] T. Ohta, Y. Endo, R. Kikuchi, C. Kabuto, N. Harada, S. Nozoe, Absolute stereochemistry of benzocycloheptenone derivatives from Cnidoscolus phyllacanthus. Tetrahedron. 50 (1994) $5659-5668$.

[23] Y. Endo, T. Ohta, S. Nozoe, Favelanone, a novel tetracyclic clyclopropane derivative from the Brazilian plant, Cnidoscolus phyllacanthus. Tetrahedron. Lett. 32 (1991) 5555-5558.

[24] Y. Endo, T. Ohta, S. Nozoe, Neofavelanone, a novel tetracyclic cyclobutene derivative from the Brazilian plant, Cnidoscolus phyllacanthus. Tetrahedron. Lett. 33 (1992) 353-356.

[25] Clinical Laboratory Standards Institute (CLSI). Metodologia dos testes de sensibilidade a agentes antimicrobianos por diluição para bactérias de crescimento aeróbico: norma aprovada. M7-A6, 2003.

[26] R.L. Brum, N.K. Honda, S.C. Hess, A.J. Cavalheiro, F.D. Monache, Acyl lupeols from Cnidoscolus vitifolius. Phytochemistry. 49 (1998) 1127-1127. 
[27] Y. Endo, T. Ohta, S. Nozoe, Favelines, novel tricyclic benzocycloheptenes with cytotoxic activities from Brazilian plant, Cnidoscolus phyllacanthus. Tetrahedron. Lett. 32 (1991) 30833086.

[28] B.Y.Q. Tien, H.M.S. Goh, K.K.L. Chong, S. Bhaduri-Tagore, S. Holec, R. Dress, F. Ginhoux, M.A. Ingersoll, R.B.H. Williams, K.A. Kline, Enterococcus faecalis Promotes Innate Immune Suppression and Polymicrobial Catheter-Associated Urinary Tract Infection, Infect. Immun. 85 (2017) e00378-17.

[29] J. Castro, D. Machado, N. Cerca, Escherichia coli and Enterococcus faecalis are able to incorporate and enhance a pre-formed Gardnerella vaginalis biofilm. Pathog. Dis. 74 (2016). ftw007.

[30] W.R. Miller, J.M. Munita, C.A. Arias, Mechanisms of antibiotic resistance in enterococci. Expert Rev. Anti. Infect. Ther. 12 (2014) 1221-1236.

[31] M.U. Rasheed, N. Thajuddin, P. Ahamed, Z. Teklemariam, K. Jamil, Antimicrobial drug resistance in strains of Escherichia coli isolated from food sources. Rev. Inst. Med. Trop. Sao. Paulo. 56 (2014) 341-346.

[32] S.A. Zacchino, E. Butassi, M.D. Liberto, M. Raimondi, A. Postigo, M. Sortino, Plant phenolics and terpenoids as adjuvants of antibacterial and antifungal drugs. Phytomedicine. 37 (2017) 27-48. 